\title{
PHYTOCHEMICAL, GAS CHROMATOGRAPHY WITH MASS SPECTROMETRY ANALYSIS OF ANDROGRAPHIS SERPYLLIFOLIA METHANOL LEAF EXTRACT AND ITS ANTIOXIDANT AND ANTIBACTERIAL ACTIVITIES
}

\author{
MADHANKUMAR R, MURUGESAN S* \\ Department of Botany, School of Life Sciences, Periyar University, Periyar Palkalai Nagar, Salem, Tamil Nadu, India. \\ Email: drsmbtpu@gmail.com
}

Received: 03 November 2018, Revised and Accepted: 09 January 2019

\section{ABSTRACT}

Objective: The present study is to evaluate the preliminary study of phytochemical screening and biological applications of Andrographis serpyllifolia methanol leaf extracts.

Methods: The methanol leaf extracts of A. serpyllifolia was prepared using Soxhlet apparatus and the extract was analyzed using gas chromatography with mass spectrometry (GC-MS). In vitro antioxidant activity was determined by superoxide dismutase, catalase, glutathione peroxidase, and glutathione S-transferase. Further, the antibacterial activity of methanolic leaf extract of A. serpyllifolia was tested against various human pathogens by using agar disc diffusion method.

Results: Preliminary phytochemical screening and GC-MS results revealed phenols, aromatic carboxylic acids, and esters in the chloroform extract to be the molecules responsible for the antioxidant and antibacterial activity of $A$. serpyllifolia methanol extract and fractions showed the presence of various secondary metabolites present.

Conclusion: The present study strongly recommended that the methanolic extract of $A$. serpyllifolia leaves possesses compounds that inhibit the growth of microbes as wells excellent antioxidant activities. The study further suggested the potential therapeutic use of these extract in cancer study.

Keywords: A. serpyllifolia, Methanol extracts, Phytochemical, Gas chromatography with mass spectrometry, Antimicrobial, Antioxidant.

(C) 2019 The Authors. Published by Innovare Academic Sciences Pvt Ltd. This is an open access article under the CC BY license (http://creativecommons. org/licenses/by/4. 0/) DOI: http://dx.doi.org/10.22159/ajpcr.2019.v12i3.30618

\section{INTRODUCTION}

Herbal medicines are being gained a lot of acceptance in recent years because they are a natively higher therapeutic window, less side effects, and scientific essential of therapeutic activities [1]. Nowadays, medicinal plants have been found to possess antimicrobial properties [2]. Many plants having several phytoconstituents, the phytochemicals play a vital role against various diseases such as asthma, arthritis and cancer. The phytochemicals are cured many diseases without causing any harm to human beings these can also be considered as "man-friendly medicines" [3]. The World Health Organization (WHO) indicated that $70-80 \%$ of the world's population depends on herbs as a primary health care source [4].

A. serpyllifolia belongs to the family Acanthaceae and is commonly known as round leaf Kariyat, Aaku chandrika. It is an irregular herb auxiliary plant species and mostly found in southern India (Tamil Nadu, Kerala, Andhra Pradesh, and Karnataka). The entire plant comprises phenols, alkaloids, steroids, saponins, flavonoids, terpenoids, tannins, anthraquinones, glycosides, phycobalamin, and sugar [5]. The bioactive compounds of $A$. serpyllifolia are related to have important biological applications such as antibacterial, antiulcer, anti-diabetic, anticancer, and anti-inflammatory activities [6]. A. serpyllifolia plant is used as traditional Indian herbal medicine for the treatment of dysentery and malaria. The plant extract is used to treat wounds and also effective in jaundice. Andrographolide has been reported as one of the potential bioactive constituents of $A$. serpyllifolia which is found to be liable for numerous clinical and pharmacological activities [7]. In many countries, medicinal plants are the most potent antimicrobial natural source, used as ethnomedicine [8]. The medicinal property of these plants lies in the presence of bioactive components. Plants are rich in a variety of phytochemical secondary metabolites, such as alkaloids, phenolics, terpenoids, and flavonoids which have been found in many studies to have significant antimicrobial activities $[9,10]$. Oxidative stress-induced by free oxygen radicals is the main reason for various degenerative diseases such as gastric ulcers, cancer, atherosclerosis, and other conditions. Medicinal plants are the source of various antioxidants acting as oxygen scavengers. Recently, attention has been focused on antioxidants from natural sources to avoid drawbacks of human-made antioxidants [11]. In recent study, the potent antioxidant activity is attributed to active compounds present large amounts in the plants [12].

Nowadays, millions of people in the world suffer from chronic wound burns without effective solutions. Burn followed by microbial infection is a very serious complication that often results in the patients' death [13]. About 45\% of mortality is recorded in burned patients as a consequence of microbial infections [14]. On the other hand, the WHO regarding drug resistance has encouraged and promoted screening and utilization of medicinal plants as a new alternative therapy against multi-drug resistant pathogens that cause severe infections and difficult-to-treat diseases [15]. Therefore, the present study reports the evaluation of phytochemical and GC-MS analysis of methanol extracts of A. serpyllifolia. Further, to assess the antibacterial and antioxidant activities of methanolic leaf extracts of $A$. serpyllifolia.

\section{MATERIALS AND METHODS}

\section{Collection of plants}

Plants of $A$. serpyllifolia were collected from Yercaud $\left(11.7753^{\circ} \mathrm{N}\right.$, $78.2093^{\circ} \mathrm{E}$ ), Salem, Tamil Nadu, India, during September. The taxonomic identification of plant was confirmed by the Botanical Survey of India, 
Coimbatore

(No.

BSI/SRC/5/23/2017/Tech/1672),

the voucher specimen of $A$. serpyllifolia (Vahl) Wight was preserved in institution herbarium.

\section{Preparations of methanol extracts}

Freshly collected plant leaves were first washed with running tap water and then thoroughly with distilled sterile water. Then, it was shed dried for 5-7 days. Dried plant materials were crushed and ground into fine powder using blender. Powdered plant material was extracted using methanol solvents $(100 \mathrm{ml})$ at $40-60^{\circ} \mathrm{C}$ in a Soxhlet apparatus. Concentrated plant extract was prepared by removing the excess of solvent and used for further experiments [16]

\section{Phytochemical analysis}

The qualitative preliminary detection of alkaloids, flavonoids, phenols, tannins, and saponins was carried out following the procedure of Harborne [17]. The preliminary phytochemicals were analyzed to detect the presence or absence of the specific phytochemical groups.

\section{Gas chromatography with mass spectrometry analysis}

The GC-MS analysis of the methanolic leaf extract of A. serphyllifolia was performed using a Perkin Elmer GC-MS (Model Clarus 680, MS-clarus $600 \mathrm{EI})$ equipped with an Agilent column $(30 \mathrm{~m} \times 250 \mu \mathrm{m} \times 0.25 \mu \mathrm{m})$. The oven temperature was programmed at $60^{\circ} \mathrm{C}$ for $2 \mathrm{~min}$ and then increased to $30^{\circ} \mathrm{C}$ for $6 \mathrm{~min}$, at $10^{\circ} \mathrm{C} / \mathrm{min}$. Helium was used as the carrier gas at flow rate of $3.0 \mathrm{ml} / \mathrm{min}$. The $1 \mu \mathrm{l}$ of the methanol extract of A. serphyllifolia was injected with split ratio10:1 at injector temperature was $260^{\circ} \mathrm{C}$. The characterization of compounds was determined based on the retention time. The spectrums of the components were compared with the database of the spectrum of known components stored in the GC-MS National Institute of Standard Technology library using Turbo mass software (5.4.0).

\section{Antioxidant activity}

The catalytic activities of antioxidant enzymes catalase (CAT) [18], superoxide dismutase (SOD) [19], glutathione S-transferase (GST) [20], and glutathione peroxidase (GPx) [19] were evaluated in methanolic leaf extracts of $A$. serphyllifolia.

Table 1: Phytochemicals screening from Andrographis serpyllifolia leaf phytochemicals methanol extract

\begin{tabular}{ll}
\hline Phytochemical test & Methanol extract \\
\hline Alkaloids & + \\
Flavonoids & + \\
Phenols & + \\
Carbohydrates & - \\
Saponins & + \\
Oil and resin & + \\
Tannins & + \\
Amino acids & + \\
\hline
\end{tabular}

+: Present, -: Absent

\section{Antibacterial activity}

The antimicrobial activity of silver nanoparticles was evaluated against Gram-positive (Staphylococcus aureus, Bacillus subtilis, Corynebacterium diphtheria) and Gram-negative (Klebsiella pneumonia, Pseudomonas aeruginosa, Pseudomonas fluorescens) bacterial by agar well diffusion method. All the microorganisms were obtained from Microbial Type Culture Collection, Institute of Microbial Technology, and Chandigarh, India. All the bacterial strains were maintained in the nutrient agar medium and subcultured frequently and used for the studies. A single colony of bacterial cultures was prepared by transferring into a tube containing $10 \mathrm{ml}$ nutrient broth and grown overnight at $37^{\circ} \mathrm{C}$. The individual microorganisms were prepared by spreading $100 \mu \mathrm{l}$ of culture on the nutrient agar plate with the help of spreader. Sterile discs were prepared by using Whatmann No.1 filter paper. The discs were placed on agar plates and different concentrations of methanolic leaf extracts $(25,50$ and $75 \mu \mathrm{g} / \mathrm{L})$ were added on the disc with the help of micropipette. The sterile distilled water was used as a control. The plates were incubated at $37^{\circ} \mathrm{C}$ for overnight in a bacteriological incubator. After $12 \mathrm{~h}$ incubation, the plates were removed and observed for the zone of growth inhibition, which will appear as clear (around the discs). The diameter of such zone of growth inhibition was measured using a meter ruler and the mean value for each pathogen was recorded and expressed in millimeter.

\section{RESULTS}

\section{Phytochemical screening}

The qualitative phytochemical screening of A. serpyllifolia methanolic leaf extracts revealed the presence of bioactive compounds such as alkaloids, flavonoids, phenols, saponins, tannins, amino acids, oils, and resins while carbohydrates was absent in the methanolic extracts (Table 1) [21] showed the phytosterols, flavonoids, phenols, alkaloids, carbohydrate, glycoside, sterols, steroids, terpenoids, and tannin while saponin was absent in methanol and aqueous leaf extracts of Rhododendron arboreum [22] also showed the presence of phenolics, flavonoids, tannin, steroids, diterpenes, and triterpenes in the methanolic extract revealed the presence of hydrocarbon alkane, steroids, ester, fatty acids, flavonoids, terpenes. The plant of Borassus flabellifer plant extract The phytochemical screening showed the presence of alkaloids, flavonoids, glycosides, saponins, tannins, phytosterols, triterpenoids, and phenols in the immature palmyra palm fruits extract [23]

\section{Gas chromatography with mass spectrometry analysis}

The GC-MS chromatogram is shown in Fig. 1 highlighted the 13 Phytocompounds present in the methanolic leaf extract of $A$. serpyllifolia. The composition of each compound was represented based on a peak area percentage. This analysis also provides the information regarding the molecular weight of each compound was in (Table 2). From the GC-MS analysis was highlight many secondary metabolites such as alkaloids, phenols, terpenoids, saponins, tannins, carbohydrate, amino acids, quanins, oils, and resins presentinthemethanolic extracts of A. serpyllifolia. The major phytochemical constituents 3,7,11,15-Tetramethyl-2-

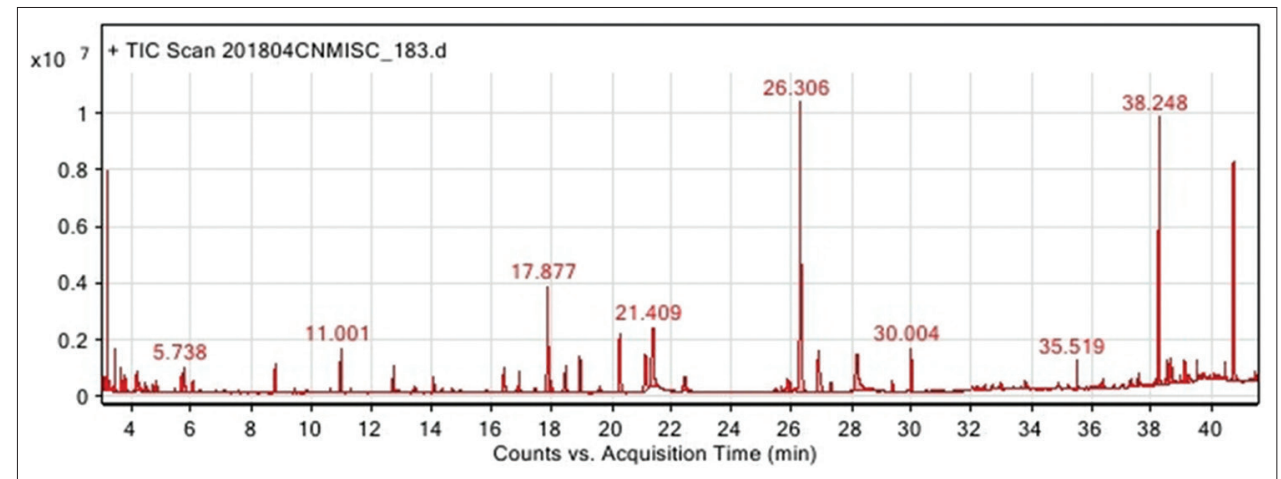

Fig. 1: Gas chromatography with mass spectrometry analysis of methanolic leaf extract of Andrographis serpyllifolia 
Table 2: Gas chromatography-mass spectrometry analysis of chemical composition identified in the methanolic leaf extract of Andrographis serpyllifolia

\begin{tabular}{llll}
\hline RT & Area & Compound name & Molecular formula \\
\hline 6.042 & 2.38 & Benzofuran, 2,2,-dihydro & $\mathrm{C}_{8} \mathrm{H}_{8} \mathrm{O}$ \\
12.761 & 3.52 & 1-hexadecanol & $\mathrm{C}_{16} \mathrm{H}_{34} \mathrm{O}$ \\
16.908 & 3.79 & n-Pentadecanol & $\mathrm{C}_{15} \mathrm{H}_{32} \mathrm{O}$ \\
17.44 & 19.94 & Pentadecanal & $\mathrm{C}_{15} \mathrm{H}_{30} \mathrm{O}$ \\
17.877 & 2.71 & $3,7,11,15-$ Tetramethyl-2-hexadecen-1-ol & $\mathrm{C}_{20} \mathrm{H}_{40} \mathrm{O}$ \\
18.967 & 8.11 & 3,7,11,15-Tetramethyl-2-hexadecen-1-ol & $\mathrm{C}_{20} \mathrm{H}_{40} \mathrm{O}$ \\
22.442 & 4.35 & n-Pentadecanol & $\mathrm{C}_{15} \mathrm{H}_{32} \mathrm{O}$ \\
25.46 & 1.59 & Cyclodexadecane & $\mathrm{C}_{16} \mathrm{H}_{32}$ \\
26.925 & 14.12 & Methyl stearate & $\mathrm{C}_{19} \mathrm{H}_{38} \mathrm{O}_{2}$ \\
29.392 & 3.83 & n-Pentadecanol & $\mathrm{C}_{15} \mathrm{H}_{32} \mathrm{O}$ \\
30.003 & 10.96 & Phytol acetate & $\mathrm{C}_{22} \mathrm{H}_{42} \mathrm{O}_{2}$ \\
38.248 & 29.95 & Squalene & $\mathrm{C}_{30} \mathrm{H}_{50}$ \\
39.083 & 2.65 & trans-Geranylgeraniol & $\mathrm{C}_{20} \mathrm{H}_{34} \mathrm{O}$ \\
\hline
\end{tabular}

RT: Retention time

Table 3: Chemical structure of identified phytocompounds in the methanolic leaf extract of Andrographis serpyllifolia by gas chromatography-mass spectrometry

\begin{tabular}{|c|c|c|}
\hline Name of the phytocompounds & Structure & Biological properties \\
\hline Benzofuran, 2,2,-dihydro- & & Liver targets \\
\hline 1-Hexadecanol & & Decreased hyperoxic in rats \\
\hline n-Pentadecanol & & Inherited human peroxisomal disorders \\
\hline Pentadecanal- & $m$ & Inherited human peroxisomal disorders \\
\hline 3,7,11,15-Tetramethyl-2-hexadecen-1-ol & & Antimicrobial \\
\hline Cyclodexadecane & & Chemical and physical properties \\
\hline Methyl stearate & & Antifoaming agent and fermentation nutrient. \\
\hline Phytol, acetate & whin & Antimicrobial, Anticancer, cancer preventive, diuretic antiinflammatory \\
\hline Squalene & xhincing & $\begin{array}{l}\text { Antibacterial, antioxidant, pesticide, antitumor, cancer preventive, } \\
\text { immunostimulant, chemo preventive, lipoxygenase-inhibitor }\end{array}$ \\
\hline Trans-Geranylgeraniol & & The biological activity of farnesol \\
\hline
\end{tabular}

Table 4: Antioxidant activity of methanol extract of Andrographis serpyllifolia

\begin{tabular}{lll}
\hline Antioxidants & \multicolumn{2}{l}{ Antioxidant activity } \\
\cline { 2 - 3 } & Standard control & Methanol extract \\
\hline SOD & $31.1 \pm 1.05$ & $26.4 \pm 0.25$ \\
CAT & $53.23 \pm 1.27$ & $44.58 \pm 2.36$ \\
GPX & $261.1 \pm 0.52$ & $231.4 \pm 1.46$ \\
GST & $172.3 \pm 2.23$ & $153.1 \pm 1.43$ \\
\hline
\end{tabular}

SOD: Superoxide dismutase, CAT: Catalase, GPX: Glutathione peroxidase, GST: Glutathione-s-transferase

hexadecen-1-ol (8.11\%), Pentadecanal (19.94\%), Phytol acetate (10.96\%) and Squalene (29.95\%) were observed in methanolic leaf extract of $A$. serpyllifolia (Fig. 1). These important bioactive compounds molecular structure and biological properties are indicated in (Table 3). Phytol is an acyclic diterpene alcohol and chlorophyll constituents. It is used as a precursor for the production of synthetic forms of Vitamin E and Vitamin k1. Vitamin E is one of the active natural antioxidants; it is the most effective chain-breaking antioxidant within the cell membrane. Vitamin E also acts in the prevention of free radical formation [24] and also phytol was most potent antitubercular activity against Mycobacterium tuberculosis H37Rv strain. Squalene is ubiquitously distributed in human tissues where it is transported in serum generally in association with very low-density lipoproteins. Squalene is also investigated as an adjunctive cancer therapy [25]. The Ruta graveolens GC-MS analysis of methanolic leaf extract revealed the presence of approximately 26 phytochemical constituents [26].

\section{Antioxidant activity}

The antioxidant activity of A. serpyllifolia was evaluated and compared with methanolic extract and standard control of ascorbic acid. The level of enzymatic antioxidants such as SOD, CAT, GPx, and GST values showed in (Table 4). The activities of SOD and CAT levels were found to be $26.4 \pm 0.25$ units/mg protein and $44.58 \pm 2.36 \mu$ mole of $\mathrm{H}_{2} \mathrm{O}_{2}$ consumed $/ \mathrm{min} / \mathrm{mg}$ proteins. SOD is one of the antioxidant enzymes that play a key role in cellular defense against ROS Bowler [27]. Similarly, CAT is also one of the major antioxidant enzymes it eliminates $\mathrm{H}_{2} \mathrm{O}_{2}$ by transforming the $\mathrm{H}_{2} \mathrm{O}$ and $\mathrm{O}_{2}$. The stimulation of SOD activity along with CAT seemed to play a protective role against membrane damage as $\mathrm{Cu}$ is particularly toxic to membranes [28]. SOD and CAT in Tylophora pauciflora were found to be $29.78 \pm 0.57$ units/mg protein and $39.87 \pm 0.51 \mu$ mole of $\mathrm{H}_{2} \mathrm{O}_{2}$ consumed $/ \mathrm{min} / \mathrm{mg}$ proteins, respectively [29]. GPx and GST levels in methanolic leaf extracts shows the high level of GPx (231.4 $\pm 1.46 \mu \mathrm{g}$ of glutathione oxidized $/ \mathrm{min} / \mathrm{mg}$ protein $)$ and $153.1 \pm 1.43 \mu$ moles of CDNB - GSH conjugate formed $/ \mathrm{min} / \mathrm{mg}$ protein.

\section{Antibacterial activity}

Biomolecule coated AgNPs showed strong antibacterial activity against various microbial pathogens such as two positive bacteria (B. subtilis and Staphylococcus epidermidis) and two negative bacteria (Escherichia coli and Salmonella typhi). A methanolic extracts was showed notable antibacterial activity against all the bacterial strains compared to controls. Methanolic extracts $(50 \mu \mathrm{g})$ exhibited the maximum zone of growth inhibition (12 mm) was obtained in B. subtilis followed by S. aureus (Table 5). Antibacterial activity results showed that the maximum zone of inhibition was observed in methanolic extracts compared to control. These results strongly suggested the 
Table 5: Antibacterial activity of methanol extract of Andrographis serpyllifolia leaf against human pathogens

\begin{tabular}{|c|c|c|c|c|}
\hline \multirow[t]{2}{*}{ Bacteria } & \multirow[t]{2}{*}{ Control (distilled water) } & \multirow[t]{2}{*}{ Antibiotic (streptomycin) } & \multicolumn{2}{|c|}{ Methanolic extract $(\mu \mathrm{g})$} \\
\hline & & & 25 & 50 \\
\hline Klebsiella pneumonia & $0.0 \pm 0$ & $12.5 \pm 0.17$ & $6 \pm 0.18$ & $9.5 \pm 0.15$ \\
\hline Staphylococcus aureus & $0.0 \pm 0$ & $14.3 \pm 0.25$ & $6.5 \pm 0.21$ & $11.5 \pm 0.24$ \\
\hline Pseudomonas aeruginosa & $0.0 \pm 0$ & $9.5 \pm 0.21$ & $5.5 \pm 0.15$ & $8.5 \pm 0.17$ \\
\hline Pseudomonas fluorescens & $0.0 \pm 0$ & $11 \pm 0.12$ & $5.5 \pm 0.12$ & $9.5 \pm 0.16$ \\
\hline Bacillus subtilis & $0.0 \pm 0$ & $16 \pm 0.17$ & $8 \pm 0.23$ & $12 \pm 0.21$ \\
\hline
\end{tabular}

biosynthesized AgNPs using aqueous extract of E. acaulis showed effective antibacterial activity against human pathogens this may be possible bioactive compounds present in the plant extracts (Table 1). The ethanolic extract of the leaves of $A$. serpyllifolia at a concentration of $1.50 \mathrm{mg} /$ disc showed excellent antimicrobial activity against $S$. Typhi [30].

\section{DISCUSSION}

This study was work phytochemical screening the present of alkaloids, flavonoids, phenols saponins oil and resin, tannins, amino acids plant leaf methanol extract (A. serpyllifolia), and antimicrobial activity for antioxidant[] the antimicrobial activities for zone inhibition for hight zone bacteria $(11.5 \pm 0.24) \quad S$. aureus, Pseudomonas floure and to the Gc-ms analysis for the natural the compound in $A$. serpyllifolia plant leaves for this current reported in this plant medicine properties or in traditional medicine for well know inflammation and pain centipede using this plant $A$. serpyllifolia.

CONCLUSION

Phytochemical and GC-MS analysis of A. serpyllifolia confirmed that the methanolic extracts were rich in phenolics, flavonoids, alkaloids, and various bioactive compounds were detected. Therefore, methanol leaf extracts of A. serpyllifolia have potential bioactive compounds which are responsible for antimicrobial activity against $B$. subtilis, Staphylococcus epidermidis, E. coli and S. typhi. The methanol extract also showed significant antioxidant properties, indicative of its potential as a source. Further research is also required for isolation and identification of active biomolecules and principles present in this extract, and hence that they could be exploited for pharmaceutical use at the industrial scale.

\section{ACKNOWLEDGMENT}

The authors are thankful to the Department of Botany, Periyar University, for providing necessary facility to carry out this study.

\section{AUTHOR'S CONTRIBUTION}

All the authors have contributed equally

\section{CONFLICTS OF INTEREST}

There are no conflicts of interest to declare

\section{REFERENCES}

1. Prakash P, Gupta N. Therapeutic uses of Ocimum sanctum Linn (Tulsi) with a note on eugenol and its pharmacological actions: A short review. Indian J Physiol Pharmacol 2005;49:125-31.

2. Mahesh B, Satish S. Antimicrobial activity of some important medicinal plant against plant and human pathogens. World J Agric Sci 2008;4:839-43.

3. Banu KS, Cathrine L. General techniques involved in phytochemical analysis. Int J Adv Res Chem Sci 2015;2:25-32.

4. Muhammad H, Gomes-Carneiro MR, Poça KS, De-Oliveira AC, Afzan A, Sulaiman SA, et al. Evaluation of the genotoxicity of Orthosiphon stamineus aqueous extract. J Ethnopharmacol 2011;133:647-53.

5. Chithra S, Murthy NK, Srinivas C. Phytochemical screening and in vitro assessment of antimicrobial and antioxidant potential of
A. serpyllifolia-an endemic medicinal plant from South India. Int J Adv Res 2014;2:917-28.

6. Sanjeevaiah N, Jithan A. Pharmacological screening of A serpyllifolia for antidiabetic activity. Int J Adv Pharma 2013;2:2277-4688.

7. Madav S, Tripathi HC, Mishra SK. Analgesic, antipyretic and antiulcerogenic effects of andrographolide. Ind J Pharm Sci 1994;57:121-5.

8. El-Shouny WA, Ali SS, Sun J, Samy SM, Ali A. Drug resistance profile and molecular characterization of extended spectrum beta-lactamase (ES $\beta$ L)-producing Pseudomonas aeruginosa isolated from burn wound infections. Essential oils and their potential for utilization. Microb Pathog 2018;116:301-12

9. Ahmed SA, Kaur G, Sharma P, Singh S, Ikram S. Fruit waste (peel) as bio-reductant to synthesize silver nanoparticles with antimicrobial, antioxidant and cytotoxic activities. J Appl Biomed 2018;16:221-31.

10. Kumar MR, Joshi SD, Kulkarni VH, Savant C. Phytochemical screening and evaluation of analgesic, anti-inflammatory activities of Peganum harmala Linn., Seeds in rodents. Int J Appl Pharm Sci 2015;5:52-5.

11. Nayak D, Ashe S, Rauta PR, Nayak BB. Assessment of antioxidant, antimicrobial and anti-osteosarcoma potential of four traditionally used Indian medicinal plants. J Appl Biomed 2017;15:119-32.

12. Gandhia PR, Jayaseelan C, Kamaraj C, Rajasree SR, Mary RR. In vitro antimalarial activity of synthesized TiO2 nanoparticles using Momordica charantia leaf extract against Plasmodium falciparum. J Appl Biomed 2018;18:221-31.

13. Tahaa H, Aryab A, Khan AK, Shahid N, Noordind MI, Mohan S. Effect of Pseuduvaria macrophylla in attenuating hyperglycemia mediated oxidative stress and inflammatory response in STZ-nicotinamide induced diabetic rats by upregulating insulin secretion and glucose transporter-1, 2 and 4 proteins expression. J Appl Biomed 2018; 16:263-73

14. Ali SS, Morsy R, El-Zawawy NA, Fareed M, Bedaiwy MY. Synthesized zinc peroxide nanoparticles ( $\mathrm{ZnO} 2-\mathrm{NPs})$ : A novel antimicrobial, anti-elastase, antikeratinase, and anti-inflammatory approach toward polymicrobial burn wounds. Int J Nanomed Nanosurg 2017;12:6059-73.

15. Bloemsma GC, Dokter J, Boxma H, Oen IM. Mortality and causes of death in a burn centre. Burns 2008;34:1103-7.

16. Kandati PV, Ch G, Reddy AS, Nath RR, Reddy R. In-vitro and in-vivo antiinflammatory activity of Andrographis serpyllifolia (Rottl. Ex Vahl.) Wt. Int Curr Pharm J 2012;1:199-204.

17. Harborne AJ. Phytochemical methods a guide to modern techniques of plant analysis. Plant Pathol 1998;48:146.

18. Sinha AK. Colorimetric assay of catalase. Anal Biochem 1972; 47:389-94

19. Rotruck JT, Pope AL, Ganther HE, Swanson AB, Hafeman DG, Hoekstra WG, et al. Selenium: Biochemical role as a component of glutathione peroxidase. Science 1973;179:588-90

20. Habig WH, Pabst MJ, Jacoby WB. Glutathione-S-transferase the first enzymatic step in mercapturic acid formation. J Biol Chem 1974;249:7130-9.

21. Rawat P, Bachheti R, Kumar N, Rai N. Phytochemical analysis and evaluation of in vitro immunomodulatory activity of Rhododendron arboreum leaves. Asian J Pharm Clin Res 2018;11:123-8.

22. Roy JD, Handique AK, Barua CC, Talukdar A, Ahmed FA, Barua IC. Evaluation of phytoconstituents and assessment of adaptogenic activity in vivo in various extracts of Rhododendron arboreum (leaves). Ind J Pharm Biol Res 2014;2:49-56.

23. Osama A, Awadelkarim S, Ali A. Antioxidant activity, acetylcholinesterase inhibitory potential and phytochemical analysis of Sarcocephalus latifolius Sm. Bark used in traditional medicine in Sudan. BMC Complement Altern Med 2017;17:270.

24. Chen JJ, Ting CW, Hwang TL, Chen IS. Benzophenone derivatives from the fruits of Garcinia multiflora and their anti-inflammatory activity. J Nat Prod 2009;72:253-8. 
25. Bowler C, Montagu MV, Inze D. Superoxide dismutase and stress tolerance. Ann Rev Plant Physiol Plant Mol Biol 1992;43:83-116.

26. Renuka K, Devi VR, Subramanian SP. Phytochemical screening and evaluation of in vitro antioxidant potential of immature palmyra palm (Borassus flabellifer Linn.) fruits. Int J Pharm Pahrm Sci 2018;9:30-4.

27. Ahmed A, Hasnain A, Akhtar S, Hussain A, Yasin AU, Wahid A, et al. Antioxidant enzymes as bio-markers for copper tolerance in safflower (Carthamus tinctorius L.). Afr J Biotechnol 2010;9:5441-4.

28. Starlin T, Gopalakrishnan VK. Enzymatic and non-enzymatic antioxidant properties of Tylophora pauciflora Wight and arn.-an in vitro study. Asian J Pharm Clin Res 2013;6:68-71.

29. AzaleworkHG, Sahabjada,JafriA,ArshadMD, MalikT. Phytochemical investigation, GC-MS profile and antimicrobial activity of a medicinal plant Ruta graveolens. From Ethiopia. Int J Pharm Pharm Sci 2017;9:30-4.

30. Gupta SS, Sharma J, Kumar GR, Pandey G, Mohapatra PK, Rawat AS, et al. Effect of $A$. serpyllifolia Leaves extract on experimentally induced typhoid using Salmonella typhi. Br J Pharm Res 2014;3:230-9. 